\title{
ANALYSIS PERCEPTION OF MICRO SMALL AND MEDIUM ENTERPRISES ON THE FINANCIAL STATEMENT BASED ON SAK ETAP
}

\author{
Isna Ardila ${ }^{1}$ Yustia $^{2}$ \\ Universitas Muhammadiyah Sumatera Utara \\ isnaardila@umsu.ac.id ${ }^{l}$,yustiasyam2510@gmail.com ${ }^{2}$
}

\begin{abstract}
The purpose of this study is about the perception of MSMEs on financial reporting in accordance SAK ETAP in financial management in MSMEs business. This research use descriptive approach by using primary data. The population in this study is MSMEs CDC Witel Medan. Sampling method in this research using saturated sampling technique amounted to 30 MSMEs. Data were collected by distributing questionnaires to registered MSMEs to be Telkom CDC-assisted partners. The results showed that the perception of MSMEs on SAK ETAP has many opinions, some argue that agree to make financial statements and some do not agree because the MSMEs do not have knowledge about accounting, do not understand to make financial statements, financial statements are not important applied in the business because not big companies, more concerned about the increase in turnover and how to grow the business becomes big.
\end{abstract}

Keywords: MSMEs, Financial, Perceptions of MSMEs, SAK ETAP

\section{INTRODUCTION}

Micro Small and Medium Enterprises (MSMEs) have proven to have a role and contribute to the Indonesian economy. According to data from the Ministry of Cooperatives and Small and Medium Enterprises, the number of MSMEs in 2015 reaches 60.7 million units and most of them are micro-scale enterprises (98.73 percent) while the total number of workers employed in this sector is 132.3 million workers. The contribution of MSMEs to the achievement of National Investment in 2015 according to the prevailing price of 192.5 trillion. This number has increased an average of 10.6 percent (Warta KUMKM). The contribution of MSMEs to Gross National Domestic Product in 2009-2013 was recorded at 57.6 percent with an average growth of 6.7 percent. The rapid development of MSMEs sector shows that there is great potential if it can be managed and developed properly which of course will be able to realize a robust small and medium enterprises.

The existence of MSMEs is reinforced with all the advantages it has. At the time of economic disaster to be a blow to the Indonesian nation that the economic crisis of 1997, the economic downturn that occurred so many parties are not prepared themselves to face this condition. However, among other countries, Indonesia is the country most not expected to be hit by the crisis when compared with other countries. This is because there are many MSMEs in Indonesia that are able to survive in times of crisis (Mansyur and Dwi 2012).

However, behind the glorious achievements shown by the existence of MSMEs, in fact there are still many problems and obstacles faced by MSMEs, including the classic constraints of the quality of Human Resources (HR), weak business networks and market penetration capabilities, the mentality of SME entrepreneurs, the lack of transparency between the early generations of SME development against the next generation of legality, as well as financial problems.

One of the determinants of the success of MSMEs is the availability of financial access from financial institutions. In order to gain access to such funding, MSMEs are required to prepare financial statements based on applicable Financial Accounting Standards. The limited human resources in preparing financial statements using IFAS-based International Financial Reporting Standards (IFRS) has become a major obstacle facing MSMEs. SAK ETAP provides for simpler accounting records than general SAK in terms of recognizing, measuring, and disclosing transactions on financial statements. 
The simplification of accounting arrangements in SAK ETAP is expected to encourage SME development in Indonesia.

Government of Indonesia through Government Regulation (PP) No. 17 of 2013 states about the existence of obligations for small business actors to perform accounting records (Rias and Patricia, 2014). This standard is designed to make it easier for MSMEs to prepare their own financial statements, which can be audited and received an opinion on the audit. The existence of relief in the preparation of financial statements with the issuance of SAK ETAP allows for the applicability of MSMEs so as to increase the trust of some external parties.

Accounting information in the form of financial statements can be useful in knowing the performance of the undertakings, becoming the basic capital for MSMEs to make decisions, measuring and communicating business financial information, for example controlling costs, measuring and increasing productivity and providing support to production processes. Accounting information allows management to implement the strategy and perform the operational activities necessary to achieve the organization as a whole. From the above opinion, a reasonable and even necessity for each business unit to present financial statements, especially when associated with the purpose of the presence of the financial statements themselves. The requirement to present financial statements is also clarified by the presence of the Financial Accounting Standards of Entities without Public Accountability (SAK ETAP).

The Government released a Government Regulation governing the special treatment of Income Tax for small, micro and medium enterprises. The Government Regulation is Government Regulation No. 46 of 2013 which was issued on June 12, 2013 and shall come into force on 1 July 2013. Under this provision, according to Sofjan, Chairman of the Indonesian Employers Association (2015) this regulation will be more beneficial to the government as MSMEs enter into but there are still many MSMEs who do not pay income tax in accordance with Government Regulation No. 46 of 2013. The use of SAK ETAP will always be related to the accounting provisions applied by the government regarding Taxable Income, or known as Tax Accounting. Such linkages result in SAK ETAP users to make fiscal corrections in tax calculations.

In accordance with the Law on KUP, it is stipulated that each Taxpayer must fill out the SPT correctly, completely and clearly in using the Indonesian language using Latin letters, Arabic numerals, rupiah currency units, and signing and submitting to the Directorate General of Taxes office where the taxpayer registered. SPT annual Taxpayers who are obliged to maintain bookkeeping shall attach the financial statements of each taxpayer. Bookkeeping should be organized in a manner or system commonly used in Indonesia. With the enactment of SAK ETAP, the calculation of taxable income of each taxpayer who does not have significant accountability is calculated by taking into account the terms of the SAK ETAP. In accordance with SAK ETAP, the purpose of the financial statements is to provide information on: the financial position, financial performance, and cash flows of an entity. The financial statements are the end result of the bookkeeping process. Based on UU KUP, that the purpose of bookkeeping is that based on the bookkeeping can be calculated the amount of tax payable.

In addition to being a form of accountability to lenders, good financial statements will also be useful if you are experiencing financial constraints and want to lend to the bank. A good financial report will help convince banks to lend. If the MSMEs do not have financial statements, then banks will have doubts about the current business conditions of MSMEs. This is certainly very detrimental, especially if the business situation is actually very developed and not in trouble.

PT. TELEKOMUNIKASI INDONESIA, Tbk or known as PT. TELKOM is one of the StateOwned Enterprises (SOEs) engaged in telecommunication facilities and services and information that was established on October 23, 1856. As a State Enterprise, Telkom is actively involved in developing Partnership and Community Development Program through Community Development Center (TELKOM CDC). Telkom CDC as a unit that supports Telkom's main business, has a strategic position to other business units in terms of empowering Micro Small Medium Enterprises (MSMEs) community to become a tough and independent entrepreneur.

In this Partnership and Community Development Program Telkom CDC has a Partner who has officially registered and the type of business to be run. The built partners are small businesses and cooperatives that get loans from the partnership program. The partner is obliged to carry out the business activities according to the plan approved by the Telecom counselor, organize the recording / bookkeeping in an orderly manner, repay the loan in a timely manner in accordance with the agreement agreed by the partner and the company, submit the quarterly business development report to Telkom coach can see and monitor the growth of the business run by each partner under the guidance of CDC Telkom Medan. 
However, in fact the condition is much different exactly happening to the perpetrators of MSMEs telkom. Many SME players do not compile financial statements. Some of the perpetrators of SME Telkom only record the amount of money received and the output, the amount of goods purchased only limited reminders only with the format and also with a reminder in the head that is not in accordance with applicable standards. When they get questions about the profit earned each period, they cannot show by nominal but with tangible assets such as land, house or vehicle. Furthermore, the asset is obtained not only by its business funds but sometimes coupled with personal property. The assets are sometimes not used for business but are used for personal purposes and there is no record or separation between the two. This has led to the development of partner businesses, especially in terms of financial performance cannot be known clearly (Setyorini 2012).

Financial Accounting Standards Entity without Public Accountability (SAK ETAP) is intended for the use of entities without public accountability. The entity without such public accountability is an entity which:

a. Has no significant accountability.

b. Does not publish general purpose financial statements for external users. Examples of external users are owners who are not directly involved in business management, creditors, and credit rating agencies.

Business entities classified as entities without public accountability are: Individual Entities, Civil Associations, Firm, Commanditare Vennootschap (CV), Limited Liability Companies, which have no significant public accountability, ETAP Use Cooperatives are directed to small and medium- apply IFRS in full. Similar to the International Financial Reporting Standards for Small and Medium-sized Entities (IFRS for MSMEs), SAK ETAP and IFRS for MSMEs are equally for entities without public accountability, only the term used in IFRS small and medium-sized entities (MSMEs).

The financial statements are one important component in an accounting system. From the financial statements can be known whether the company is healthy or not. Based on applicable regulations, the reporting of Small and Medium Enterprises financial statements can use SAKETAP.SAKETAP is a financial accounting standard for entities without public accountability. SAKETAP can be used as a solution for medium and small enterprises as a reference for preparing financial statements. This relates to the simpler arrangement of financial statements compared to financial statements which are based on Statement of Financial Accounting Standards (PSAK).

According to SAK ETAP (2016) "The purpose of the financial statements is to provide information on the financial position, financial performance, and cash flows of an entity beneficial to a large number of users in economic decision making by anyone not in a position to request special financial statements to meet the information needs certain. In fulfilling its objectives, the financial statements also indicate what management has done or accountability for the resources entrusted to it.

The term perception is often referred to as a view, picture, or budget, because in the perception there is a response of a person about one thing or object. According to Slameto (2010) perception is a process that involves the entry of messages or information into the human brain, through human perception of continuous relationship with the environment. This relationship is done through the senses, namely the sense of sight, listener, touch, taste, and smell.

Perceptions of Objectives The financial statements are the views, views or assumptions of business owners on the purpose of financial statements. To measure this variable, researchers used three indicators (Ardhian 2013), namely:

1) Perceptions of the purpose of financial statements to provide information on the company's financial position.

2) Perceptions of the purpose of financial statements to provide company performance information.

3) Perceptions of the purpose of financial statements to provide information on changes in financial position.

According to Law (UU) No. 20 Year 2008 About MSMEs, understanding of MSMEs are:

1. Micro Enterprises shall be productive businesses owned by natural persons and / or individual bodies that meet the criteria as stipulated in this law.

2. Small-scale business is a stand-alone productive economic enterprise undertaken by an individual or business entity that is not a subsidiary or not a branch of a company owned, controlled, or becomes part of either a direct or indirect business of a medium-sized or large-scale business that meets the criteria as intended in this law. 
3. Medium Enterprise is a stand-alone productive economic enterprise, conducted by an individual or a business entity that is not a subsidiary or not a branch of a company owned, controlled, or becomes part of the direct or indirect of a small business or a large business that complies with the criteria as referred to in this law.

As the main reference of SME criteria, in this study refers to Law no. 20 Year 2008 on Micro, Small and Medium Enterprises, namely:

a. The Micro Business Criteria are as follows:

1) Having a net worth of at most $\mathrm{Rp} 50,000,000.00$ (fifty million rupiah) excluding land and building of business premises; or

2) Having annual sales of at most Rp 300,000,000.00 (three hundred million rupiah)

b. Small Business Criteria are as follows:

1) Having net worth of more than Rp 50,000,000.00 (fifty million rupiah) up to a maximum of $\mathrm{Rp}$ $500,000,000.00$ (five hundred million rupiah) excluding land and building of business premises or;

2) Having annual sales of more than Rp 300,000,000.00 (three hundred million rupiah) up to a maximum of $\operatorname{Rp} 2,500,000,000.00$ (two billion five hundred million rupiah)

c. Medium Business Criteria are as follows:

1) Having net worth of more than $\mathrm{Rp} 500,000,000.00$ (five hundred million rupiah) up to a maximum of $\mathrm{Rp} \mathrm{10,000,000,000.00} \mathrm{(ten} \mathrm{billion} \mathrm{rupiah)} \mathrm{excluding} \mathrm{land} \mathrm{and} \mathrm{building} \mathrm{of} \mathrm{business}$ premises or

2) Having annual sales proceeds of more than $\mathrm{Rp} 2,500,000,000.00$ (two billion five hundred million rupiah) up to a maximum of $\mathrm{Rp} 50,000,000,000.00$ (fifty billion rupiahs).

\section{RESEARCH METHODS}

In this study the authors use descriptive research approach method. Descriptive method is to collect, manage, and interpret the data obtained so as to provide a clear picture of the circumstances studied. In this study the authors describe the effect of perceptions of MSMEs on financial reporting on the Partnership and Community Development program PT. Telekomunikasi Indonesia.

The data source used is primary data is data obtained directly from the object under study. Primary data obtained by distributing questionnaires to MSMEs telkom actors.

Population is a generalization area consisting of Objects / Subjects that have certain qualities and characteristics established by the researcher to be studied and then drawn conclusions (Sugiono 2012). The population in this study were 30 partners of MSMEs Partnership and Community Development program of PT.Telkom Medan branch.

The sample of this research are 30 partners of PT. Telkom witel Medan. Sampling in this research is determined by saturated sampling technique, which is sample determination technique when all member of population used as sample.

The analytical technique in this research uses descriptive analysis. Where the purpose of descriptive analysis is to provide a description of the perception of MSMEs on financial reporting in order to assess the development of MSMEs (whether very high, high, medium, low or very low).

\section{RESULT}

This study was conducted to find out how the perception of MSMEs on financial reporting on CDC Telkom Witel Medan. Information needed in this study is data obtained from questionnaires in the form of questions and this study is:

1. Provide Financial Position Information with the following statement:

a. Economic resources.

For this statement respondents who answered agreed at $73.3 \%$, and answered strongly agree $26.7 \%$, meaning that MSMEs agree to have adequate economic resources for their business. Because resources are an important factor for MSMEs business continuity. 
b. Assess the amount of cash receipts

As many as $10 \%$ disagree, $80 \%$ agree, and $10 \%$ strongly agree, meaning that the parties agree to assess the amount of cash they receive in running the business so that MSMEs know how much cash they earn in each period and the progress of MSMEs.

c. Long term cash availability.

In this statement respondents answered disagree as much as 6.7\%, 23.3\% answered less agree, $60 \%$ of respondents answered agree, and respondents answered agree with the amount of $10 \%$, meaning that MSMEs agree to provide information about long-term assets in order to know the amount of assets owned perpetrators of MSMEs during the business.

2. Provide Financial Performance Information with the following statement:

a. Assess the financial performance of a period.

This statement respondents strongly disagree with the $3.3 \%$, as many as $6.7 \%$ respondents answered less agree, answer agreed with the number of $53.3 \%$ and answered strongly agree with the amount of $36.7 \%$, some respondents opted not agree and most of SME chose to agree to provide information on business financial performance MSMEs that relate between income and expenses of the entity as a measure of return on investment / venture capital of MSMEs.

c. Financial performance of the current period and the previous period.

This statement as much as $16.7 \%$ of respondents disagreed, as many as $53.3 \%$ of respondents answered agree, and as many as $30 \%$ of respondents answered strongly agree, meaning that many MSMEs agree to provide information financial performance of the current period and previous period useful to see the progress of business in obtaining cash and paying the business expenses in order to make a decision.

c. Assess the effectiveness of financial performance.

This statement respondents answered less agree as much as $6.7 \%$, respondents agreed with the number of $76.7 \%$ and $16.7 \%$ of respondents answered strongly agree, meaning the actors agree to provide information to assess the effectiveness of business financial performance of MSMEs in order to see the development of MSMEs.

3. Provide Information of Change Financial position with the following statement:

a. Earn cash

This statement respondents disagreed $6.7 \%$, respondents answered less agree $3.3 \%$, respondents answered agree $73.3 \%$ and responden answered strongly agree $16.7 \%$, meaning many MSMEs agree to provide information about obtaining cash earned during running a business, not a personal cash which MSMEs combine with the proceeds from the business.

b. Acquisition and use of capital.

This statement respondents answered less agree 10\%, as many as $66.7 \%$ of respondents answered agree, and as many as $23.3 \%$ of respondents answered strongly agree, meaning that many MSMEs agree to provide information about the acquisition and use of capital in the business, and how the use of such capital is used.

c. Assess the operation activity of a period.

This statement respondents answered less agree $16.7 \%$, and as many as $83.3 \%$ of respondents answered agree, meaning the perpetrators agree to provide information to assess the activities of the operation of a period to find out how business operations conducted by MSMEs in the period.

4. Responsible for the execution of its functions with the following statement:

a. Make report according to accounting standard

This statement respondents disagreed $13.3 \%$, as many as $43.3 \%$ of respondents answered less agree, and respondents agreed answer 43.3, meaning that some MSMEs feel able to make financial statements in accordance accounting standards and some others unable to make reports according to accounting standards. This is influenced by the knowledge and opinions of MSMEs on the report in accordance with the prevailing accounting standards.

b. Make report according to accounting standard every period.

This statement respondents answered not agree 3.3\%, as many as $40.0 \%$ of respondents answered less agree, and $56.7 \%$ of respondents answered agree. Some MSMEs feel able to provide financial statements every period and some others cannot afford. This is influenced by the 
knowledge and opinions of MSMEs on the benefits of information received in the preparation of the appropriate standard financial statements.

5. Report the results of operations with the following statement:

a. Able to classify property, debt and capital.

This statement respondents answered not agree $13.3 \%$, as many as $30 \%$ of respondents answered less agree, and as many as $56.7 \%$ of respondents answered agree. Of all respondents, $56.7 \%$ of respondents felt able to classify property, debt and capital in order to know the type and amount of property owned, the type and amount of trade payable to be paid and the type and amount of business capital. This is influenced by the knowledge and opinions of MSMEs the importance of classifying the types of assets, debt and capital in MSMEs business.

b. Able to classify revenue and expenses

This statement respondents answered disagree 3.3\%, as many as 30\% of respondents answered less agree, and as many as $66.7 \%$ of respondents answered agree. For this question, UKM actors almost all answer in agreement because they feel able to classify the income and expenses in the MSMEs business. This is influenced by the opinion of MSMEs on the matter.

c. Able to create a journal of financial statements

This statement respondents answered not agree $6.7 \%$, as many as $26.7 \%$, respondents answered less agree, as many as $56.7 \%$ of respondents answered agree, and as many as $10 \%$ of respondents answered strongly agree. This is influenced by the knowledge and opinion of MSMEs the importance of keeping a journal of each transaction in order to know the activities undertaken in the business.

6. Report the results of operations with the following statement:

a. Able to make financial transactions in business.

This statement respondents answered less agree $6.7 \%$, as many as $76.7 \%$ of respondents answered agree, and as many as $16.7 \%$ of respondents answered strongly agree. MSMEs are of the opinion that it is important to make financial statement transactions for every financial transaction in the business operation activity. This is influenced by the knowledge and benefits gained by MSMEs the importance of making financial transaction reports for the sake of business.

7. Report the financial condition with the following statement:

a. Able to present income statement each period.

This statement respondents disagreed $6.7 \%, 3.3 \%$ respondents answered less agree, as many as $73.7 \%$ of respondents answered agree, and as many as $16.7 \%$ of respondents answered strongly agree. Many MSMEs argue that it is important to make an income statement to see the progress of the business. This is influenced by the knowledge and opinions of MSMEs on the benefits received to make business decisions.

b. Able to present income and expense report.

This statement respondents answered not agree $6.7 \%, 36.7 \%$ respondents answered less agree, as much as $36.7 \%$ respondents answered agree, and as much as $20 \%$ of respondents answered strongly agree. This is influenced by the knowledge and opinions of SME players in the presentation of income and expense reports.

8. Reporting long-term resources with the following statement:

a. This statement respondents answered disagree $6.7 \%, 33.3 \%$ respondents answered less agree, $43.3 \%$ respondents answered agree, and $16.7 \%$ of respondents answered strongly agree. This is influenced by ignorance and has not felt the benefits received by MSMEs on financial statement information to develop the business and as a means of decision makers for business continuity.

b. Able to develop financial reports as information.

This statement respondents answered less agree $30.0 \%, 50 \%$ of respondents answered agree, and as many as $16.7 \%$ of respondents answered strongly agree. This is influenced by ignorance and has not felt the benefits received by SME actors on financial statement information to develop the business and as a means of decision making for business continuity. 


\section{DISCUSSION}

From the description of descriptive statistical data respondents' answers can be concluded that the perceptions of MSMEs on financial reporting answer agreed to all statements given to the respondents MSMEs and of the agreed answers some of the actors assume important financial statements are made so that MSMEs know the conditions and developments businesses where financial statement information can be used as a basis for decision-making for the sustainability of their business.

However, although all respondents answered that they were able to make their business financial statements but what happened in the field when asked to make simple financial statements many actors could not make the report, this is due to several factors such as: MSMEs do not have knowledge of accounting so they argue that financial statements are made only by large corporations, low levels of education that make MSMEs do not understand financial reporting and do not know that information from financial statements affects their business development.

This study uses questionnaires so that the data collected only describes the opinions of MSMEs on MSMEs financial reports, so that researchers cannot control the answer of MSMEs that do not show the real situation. Questionnaires can also generate the resulting data have a chance of occurrence of inconsistency because of differences in perception between the study and the owner of MSMEs to the questions posed. At the time of return of questionnaires many MSMEs answered agree when MSMEs do not understand about accounting, do not understand to make financial statements. The reason why UKM respondents agree is that they are afraid that they will have an effect on the sustainability of their business activities such as not getting a loan from CDC telecom again.

Factors that influence perceptions of MSMEs to Financial Reporting is to know all the activities of each transaction to be recorded clearly and neatly in accordance with the chronological events of each transaction, earnings can be known the number well and become an accurate source of information for entrepreneurs of all business activities, in addition to accounting SME actors can do a revaluation of the performance of companies that can conclude the strategy that will be done so that the business continues to advance and develop, and to convince outside parties in the process of investment because it must have accounting presentation in order to account for all business activities.

\section{CONCLUSION}

Based on the results of the research it can be concluded that MSMEs do not prepare financial statements for not knowing about accounting so they do not know how important recording and bookkeeping for their business continuity, MSMEs do not consider it important to make a financial report because the financial statements are only used by large companies and do not understand the making of financial statements, The MSMEs responders agreed that they were able to make a financial statement of their business but that happened on the ground when asked to make a simple financial report many MSMEs could not make the report, and MSMEs are more concerned about more important things such as an increase in monthly turnover and how to grow a business bigger than making a financial statement of his business.

\section{SUGGESTION}

Based on the conclusion of the above research results, then the researchers can submit some suggestions as follows It is better for MSMEs to make financial statements in order to obtain convenience, not only to ease credit from creditors, but also to control assets, liabilities and capital and revenue planning and efficiency costs that occur as a tool for future business decisions. MSMEs should also follow coaching and training conducted by Telkom or government, business and community through the provision of guidance and strengthening to grow and improve the ability of MSMEs to become a strong and independent business. 


\section{REFERENCES}

Ardhian Krisnaditya. 2013. Analisis Persepsi Umkm Atas Tujuan Laporan Keuangan, Studi Kasus Pada Kecamatan Wonogiri, Kabupaten Gunungkidul. Journal.Students.Uny. Accessed [January 16 2018].

Ikatan Akuntansi Indonesia. 2016. Standart Akuntansi Keuangan Entitas Tanpa Akuntabilitas Publik. Jakarta: Cetakan Kelima.

Mansyur, Pratiwi And Dwi Indah. 2014. Persepsi Pelaku Usaha Mikro Kecil Menengah Atas Penggunaan Laporan Keuangan (Studi Empiris Pada Ukmk Mitra Binaan Pt. Telkom Indonesia, Tbk Wilayah Vii Kti). Fe Universitas Hasanuddin Makassar, Repository.Unhas.Ac.Id.

Peraturan Pemerintah Ri No 17.2017. Tentang Sinkronisasi Proses Perencanaan Dan Penganggaran Pembangunan Nasional.

Rias Tuti And S, Patricia Febrina Dwijayanti. 2014. Faktor-Faktor Yang Mempengaruhi Pemahaman Umkm Dalam Menyusun Laporan Keuangan Berdasarkan Sak Etab.The $7^{\text {th }}$ And Doctoral Colloquium. Fakultas Bisnis Dan Pascasarjana Ukwms. 157 - 170.

Setyorini, Dhyah. 2012. Pelatihan Akuntansi Umkm Bagi Usaha Mikro Kecil Menengah (Umkm) Untuk Meningkatkan Kinerja Keuangan Perusahaan”. Laporan Kegiatan Program Pengabdian Masyarakat: Universitas Negeri Yogyakarta.

Slameto. 2010. Belajar Dan Faktor-Faktor Yang Mempengaruhinya. Jakarta: Rineka Cipta.

Sugiono. 2012. Metodologi Penelitian Bisnis. Bandung: Alfabet.

Undang - Undang Ri No.20 Tahun 2008 Tentang Umkm Bab Iv Pasal 16. Jakarta.

Warta Kumkm. 2016. Penguatan Umkm Untuk Pertumbuhan Ekonomi Yang Berkualitas. Vol 5, No.1. 